\title{
Article
}

\section{Alliances in action: Opportunities and threats to solidarity between workers and service users in health and social care disputes}

Mckeown, Mick

Available at http://clok.uclan.ac.uk/4128/

Mckeown, Mick ORCID: 0000-0003-0235-1923 (2009) Alliances in action:

Opportunities and threats to solidarity between workers and service users in health and social care disputes. Social Theory and Health, 7 (2). pp. 148-169. ISSN 1477-8211

It is advisable to refer to the publisher's version if you intend to cite from the work. http://dx.doi.org/10.1057/sth.2009.8

For more information about UCLan's research in this area go to http://www.uclan.ac.uk/researchgroups/ and search for <name of research Group>.

For information about Research generally at UCLan please go to http://www.uclan.ac.uk/research/

All outputs in CLoK are protected by Intellectual Property Rights law, including Copyright law. Copyright, IPR and Moral Rights for the works on this site are retained by the individual authors and/or other copyright owners. Terms and conditions for use of this material are defined in the policies page. 


\section{Alliances in action: opportunities and threats to solidarity between workers and service users in health and social care disputes.}

\section{Abstract}

This paper reflects upon the recent mental health nurses' strike following the sacking of Karen Reissman by Manchester Mental Health and Social Care Trust. Nursing strikes are rare, though there is a significant strand of militancy in the history of nursing. Analysis of the Manchester dispute and associated media coverage is relied on as a point of departure for a more general discussion around issues of solidarity and connections between trade union and service user activism. These issues are explored in a context of the industrial and social relations of mental health care. It is argued that regressive, stereotypical representations of mental health, which appeal to fears surrounding public safety, are a feature of this industrial relation territory. The paper proposes that social relations of work and connections with the wider community could be transformed by a dual strategy: pursuing a more progressive and inclusive understanding of mental health and building stronger alliances between trade union, community and service user activists.

Key words: Nursing, trade unions, mental health, service user movement, strikes, alliances.

\section{Introduction}

The recent strike of mental health nurses in dispute with Manchester Mental Health and Social Care Trust over first the suspension and then sacking of their colleague and Unison shop steward is an important example of resistance in the modern NHS. This action connects with a lineage of radicalism that has often been neglected in published historical accounts of nursing. In this paper, the Manchester strike forms the backdrop for an analysis of the interaction between the trade union's campaign 
and media coverage of the dispute. These will be discussed in terms of the implications for alliances and solidarity between trade unions and the service user movement in a context of mental health and the future direction for mental health services.

The trade union campaign and associated media coverage raises interesting questions about the portrayal of mental health service users where industrial action seeks to defend public services amidst the threats posed by a prevailing neo-liberal politics (McKeown, Spandler \& Cresswell 2008). These issues connect with wider strategic problems for trade unions in terms of a tailing off of membership, power and influence. The paper develops an argument that trade unions can begin to reassert their influence by making efforts to establish more effective alliances with non-labour orientated social movements and communities.

\section{Striking Nurses}

Historically, the industrial relations territory for nursing has been complicated by a pursuit of professional status, images of nurses as a largely passive workforce, subordination within medical and gender hierarchies, low union density and divided union representation (Hart 2004). The two largest contemporary UK nursing unions are the Royal College of Nursing [RCN], which prefers to be known as a professional association, and the TUC affiliated UNISON, formerly comprised of NUPE, NALGO and COHSE. A strong undercurrent of radicalism does emerge in nursing histories, akin to that identified amongst social workers (Cox 2008), though this has often been airbrushed from orthodox accounts (Carpenter 1988, Hart 1994, McKeown et al 1999).

There is consistent international evidence in recent decades indicating the willingness of nurses, given the right circumstances, to undertake strike action or 
threaten it to secure bargaining goals. Nursing strikes have occurred in numerous and diverse economies including examples in the United States, Australia, New Zealand, South Africa, Canada, Japan, Israel, India, and across Europe, including the Republic of Ireland and the UK. There have also been a number of significant strikes by nurses in the developing world, particularly Africa, often associated with the negative effects of economic structural adjustment programmes demanded by the World Bank and western donors resulting in lengthy backlogs of unpaid wages.

Media reporting of the national Irish nurses' strikes of 1999 and 2002 highlighted the crucial role of public support in sustaining the action. In 2002 the president of the Irish Patients Association supported the strike and was quoted as saying: 'Patients are being used as pawns in a showdown between the government and the nurses. The justifiable cries of frustration from nurses and healthcare workers are nothing compared to the frustration of patients with the system' (Associated Press Worldstream 2002). Similarly, striking nurses were reported as being acutely conscious of the need to sustain public support and fearful that the strike could actually engender anger towards the nurses (Pogatchnik 1999).

Notable UK examples include the long running conflicts of 1982 and 1988. The first led to the establishment of a National Pay Review Body, the second became linked to the implementation of the Clinical Nurse Grading structure (DHSS 1988). The politics of this process have been outlined by Gavin (1995), and it could be argued that the perceived unfairness of the grading review was a major factor in the politicisation of British nurses.

In 1994, in London, UNISON led a successful campaign of industrial action in the defence of jobs and services at University College Hospital [UCH] (Friend 1994, Jennings \& Western 1997). The 1995 pay dispute saw the RCN begin to assert a more industrially orientated strategy by reversing its longstanding no strike commitment 
(Brindle 1995, Gray 1995). Concurrently, UNISON and the representative bodies of a range of other health care professionals sought and achieved successful ballot results for strike action (Day 1995a). McKeown and colleagues' (1999) study of nurses' industrial relations at this time suggested that nurse were quite capable of framing their concerns in a discourse of militancy. The threat of further strike action at $\mathrm{UCH}$, in support of sacked nursing shop steward Mike Carr, forced his reinstatement (Day 1995b). The 2008 pay bargaining process led to a UNISON ballot where a three year pay deal was accepted but rejection would have made industrial action inevitable.

\section{Servicing versus Participation: different ways of organising}

Considering factors that might sustain or impede industrial action, wider features of $\mathrm{NHS}$ and trade union organisation and strategy come into play. Decentralisation of the NHS into Trusts and Foundation Trusts militates against escalation of local disputes into national action, especially in the context of current anti-union laws. As the NHS has fragmented, the health and social care trade unions have merged and consolidated. There has also, arguably been some strategic convergence between the RCN and other unions; the traditional unions taking more of an interest in professional issues and the RCN beginning to encroach on the territory of health care support workers, previously not eligible for membership. Both UNISON and the RCN are currently expanding the range of services they offer. There is a tendency to promote benefits such as holiday discounts, insurance and other financial services; whilst more traditional union functions are de-emphasised (e.g. UNISON 1994, Carter \& Poynter 1999).

This chimes in with an emerging privatisation of union membership, running counter to more traditional notions of collectivism, and linking to the sort of discourse which underpins notions of passivity in workplace relations for nurses (McKeown et al 1999). The typical nurse union member is increasingly in a private relationship with their union, relatively disconnected from peers. A focus on services shifts the emphasis from 
industrial relations and relationships to a commodification of the nature of union, whereby the member becomes a consumer or customer rather than an active participant. Of course, such trends are not confined to the nursing unions, and can be seen to be discursively compatible with elements of both 1980s free-market Tory rhetoric and New Labourism. Phelps-Brown (1990) argues that the adoption of individualism into the organisation of trade unions runs so counter to their foundational principles as to constitute the beginning of the end for labour movements. Waddington \& Kerr (1999a) researched reasons for members leaving Unison and found the factors most likely to reduce membership turnover were associated with improving workplace organisation such that people felt more supported, had more contact with stewards, and experienced improved communication. Consumer orientated packages of financial services had minimal impact upon membership retention (Waddington \& Kerr 1999b)

Jarley (2005) bemoans a servicing model of trade union organisation wherein the members become dependent on the interventions of full-time officers in a way which is contrary to historical forms of mutual support. One alternative is to boost the role of lay stewards within trade union structures, but this in itself risks burn-out for the committed activists. Jarley's solution is to strengthen and expand social capital within the union, bringing together mutual support over a range of issues, not all of which will be immediately recognisable as relevant to union objectives. The collectivism that emerges would raise possibilities for connections between trade union activity and broader community interests. Hyman (2007: 12) extends these ideas with reference to the work of Law and Mooney (2006) to suggest that for unions to return to 'broad networks of mutuality' could underpin a form of 'insurgent social capital' that is better placed to fight the 'remorseless drive of neo-liberalism'.

Carter and Poynter (1999) analysed Unison's organising practices in the immediate years after its formation. There was an initial vision for a participatory organising model, 
emphasising a culture of inclusion and constituting representative structures such as self-organised groups to facilitate the activism of various minorities. This focus on democratic structures was possibly to the neglect of workplace activism. There were also tensions in the hangover from models associated with the previous constituent unions. NUPE favoured a centralised, servicing approach, at odds with the more decentralised NALGO traditions. Whilst Unison is unlikely in the near future to move too far away from a servicing model (with activists already stretched and over-burdened, and the need to support weaker areas of organisation emerging as the major employers are decentralised, reorganised or privatised) there is a need to plan for how best to balance the autonomy of activists with their need for appropriate support or confidence building. Unison's strategy is to invest in workplace organising focused upon lay activisits, with full-time regional officers picking up more serious cases of representation and supporting branch development, and national officers supporting sector level issues such as national pay and conditions bargaining or campaigning.

Despite these enduring tensions between servicing and participatory models, there are tentative signs that indicate possibilities for new forms of organising. For example, the Health sector of Unison are currently piloting a 'relational' model of organising in one branch in the South Eastern region, based upon the experiences of the Harvard Union of Clerical and Technical Workers (Hoerr 1997); this builds solidarity and empowers members based on a foundation of workplace connections, friendships and resourcefulness. Other Unison activities, notably around the Living Wage campaign and London Citizens, suggest a growing affinity for connecting with coalitions of community activism (Unison 2008, Littman 2008, Wills 2007, Bayley 2006).

In a context of nursing industrial relations, the issue of service users' welfare is prominent together with anxiety that this may be compromised as a consequence of industrial action. Hart (1994) coined the term clinical militancy to capture the 
complexities of the relationship between militant nursing actions and concerns for patients. Interesting questions and discussion points arise when we consider this central regard for patients in the contemplation and prosecution of industrial action in health care services. One of the most obvious possibilities is the potential for service user and trade union objectives to coincide or interact. This raises the potential for industrial disputes to comprise of an alliance between trade unionists and service user or community activists - in defence of cuts to services for instance. This would afford consideration of a number of associated themes and issues, including the nature of community and personhood, power dynamics within alliances and the need to establish more egalitarian relationships than those typically at stake in the provision of care, and the rhetoric that sustains and promotes the action. Exploration of these themes can reveal a real potential to address problems in previous relationships, especially where this has resulted in iniquitous power imbalances and stigmatised identities for service users. This potential, then, includes the possibility to realise a common humanity and more positive identities amongst activists, whether they originate from the staff or service user side of the fence.

\section{Trade union, community and service user alliances}

The idea that traditional trade unions, faced with fragmentation of workplaces, globalising economies, deindustrialisation, and technological change, need to form more broadly based political alliances with community groups has been mooted for a number of years now (Tufts 1998, Wills 2001, Cranford \& Ladd 2003, Wills \& Simms 2004). This community unionism is seen as one possible solution to organisational problems arising from the prevailing political economy but may also assist in addressing some glaring trade union blindspots. These include the need to do a better job of recruiting and supporting women and people from ethnic minorities, workers in small workplaces, and those with increasing insecurity of employment, on part time or temporary contracts. To achieve this, unions must begin to build 
'alliances beyond the walls of the workplace' (Wills 2001: 465). As far back as Doyal (1979) in her seminal account of the political economy of health, it has been noted that industrial action to defend the NHS has significantly involved people from local communities as well as health workers. Doyal comments that such action is as much about opening up the debate about who has a say in decision making and the control of services. Interestingly, Doyal (1979: 214) suggests that despite such struggles being largely defensive, there is a need:

... to move beyond the mere existence of a National Health Service towards the organisation of the sort of health care needed by the majority of patients.

In the mental health context, Sedgwick (1982) has called into question the failings of workers, trade unions and the wider left to think clearly about the basis for addressing social change on the basis of common interest with service users. Indeed, the labour movement has had a chequered history in relation to the politics of mental health, and trade union and patients' interests have not always coincided. Wills and Simms (2004) point out that service users might be reluctant to enter into an alliance with those staff they hold responsible for failings in services. Despite this Sedgwick saw it as an important political necessity for the creation of alliances between service user movements and others concerned with transformational politics.

Hyman (2007) goes further to argue that the unions' very legitimacy and survival depend upon the establishment of new identities and new vocabularies, bringing meaning to strategic programmes. This would involve both returning to conceiving of themselves as campaigning organisations concerned with rights and engagement with politics of contention and building new democratic relationships between activists and leadership. Jarley's (2005) analysis is referred to, in that this form of 
organisation would tap into and extend the networks of mutuality amongst the membership. This might then also involve co-operation and mutual support between trade unions and other social movements. Monahan (2000) reported on such synergy following anti-capitalism demonstrations in Washington D.C., where demonstrators on global issues turned their attention locally to support a 42 day nurses' strike. Activists remarked that 'issues that brought together activists from labor, the environment and human rights groups in Washington are similar to the striking nurses battle against a for-profit medical corporation' (Monahan 2000).

Hyman (2007) suggests that it is becoming increasingly difficult for trade unions to encourage members and potential recruits to conceive of a common interest in a context of diversity and difference, multiplicity of social identities, subjectivities and inter-subjectivities where the desired outcome is a strengthening of collectivism. He cites the German scholar Zoll (1991) who argues that this sort of complexity can only be successfully navigated if trade unions welcome difference and emerge as 'discourse organisations'.

\section{The Mental Health Service User Movement}

In the history of psychiatric and mental health services there has always been a tradition of resistance and speaking out against oppressive practices and in defence of rights and entitlements (Campbell 1996). Those who use services, have survived services or who choose not to use them have arguably become more organised. A process of radicalisation occurred in the 1970s (Spandler 2006), and latterly commentators have referred to organised service users as a new social movement with emancipatory goals (Rogers \& Pilgrim 1991, Allsop et al 2004, Williamson 2008). The idea of a mental health service user movement alongside other health and welfare movements is now so well established that Crossley $(1999,2002)$ has questioned their 'newness'. 
Spandler (2006) has written an interesting social history of the birth of the Mental Patients Union in the course of a dispute to keep open Paddington Day Hospital. She describes a process whereby staff and service users come together in defence of services, then this alliance leads to more sophisticated discussions of the actual shape and democracy of future services. Arguably, particular circumstances around the organisation of mental health care at the time, including the sense of solidarity and mutuality engendered in therapeutic communities, assisted in the development of the alliance.

In this context, regardless of the many similarities, there is an important representational difference between mental health nurses and nursing in general. Most obviously, this is worked out in the contested nature of mental health in society and in its historical relationship with medicine. Powerful representations of madness linked to dangerousness are problematic, as is the sense that mental health nurses are not dealing with 'illness' in any straight forward way. Simplistic campaigns to alter negative stereotypes of people with mental health problems have typically been formulated around a notion of stigma which works with a mantra that mental illness is an illness like any other. This is contrary to more progressive conceptualisations of mental health. For instance, it can be seen to link to examples of victim blaming in a context of discrimination, or unhelpfully de-emphasise personal agency and creativity, tapping into images of individuals as enduringly vulnerable and passive. Farrow \& O'Brien (2005) conducted a discourse analysis of media coverage of a mental health nurses' strike in New Zealand and found that mainly deprecatory depictions of both mental health nursing and mental health service users were deployed. 
Karen Reissman, shop steward of the local Unison branch, was first suspended and then sacked for speaking to the media regarding concerns about management plans for the re-organisation of services. The employer, Manchester Mental Health and Social Care Trust, argued that Karen was in breach of procedure by raising these concerns externally, and claimed her actions had brought the Trust into disrepute, constituting gross misconduct. Unison presented the action as a defence of both freedom of speech and the rights of union activists and members to operate ordinary trade union principles and activities. Short waves of strike action followed the initial suspension, and an indefinite strike was called following her sacking. This action was suspended in December 2007, but the campaign to reinstate Karen has been taken up nationally by Unison whilst also pursuing a claim for unfair dismissal at an Employment Tribunal. Further strike action has not been ruled out. Interestingly, the strikers' case was reasonably well depicted in the media, especially the employer's convoluted justification for the sacking.

Arguably, industrial action in the NHS is won or lost not just through the actions of striking colleagues but in the garnering and holding of public opinion. In previous health care strikes public support can prove to be fickle - with strong affinity for the interests of nurses, playing up to their stereotypical identity as vocational, self-sacrificing 'angels' vulnerable to the first reporting of serious detriment to patient care, or worse, the death of a patient. This can be most keenly felt when disputes are played out in general health services or paediatric hospitals, rather than community care or mental health services, where the public's attitudes towards the patients can be at best ambivalent or confused. The government and employers can operate at the fault lines of public opinion attempting to undermine public support for action. For instance, it often suits government to utilise the 'angels' image of nursing in ways which trap nurses in a position of passivity. Conversely, the previously lauded angels can quickly become just another set of intransigent public sector workers, resisting change for the sake of it 
(McKeown \& Mercer 2000). In the coverage of the Manchester dispute however, the vocational image of nursing was almost entirely absent. The idea of nurses as activists, particularly Karen herself, was quite prominent and on the whole this was depicted positively as resistance to perceived wrongs.

Media coverage stresses the merits of the case for reinstating Karen - emphasising freedom of speech, the value of whistleblowing, and the mistakes and high-handedness of management in the Trust. Trust managers were also ridiculed for their personal behaviour such as taking expensive holidays instead of remaining in post to negotiate resolution of the dispute. Critical coverage of decisions to relocate patients were described in ways that highlighted potential for harm and distress and reported the upset caused to striking nurses because of this. This coverage is positive for the union side, does not damage the relationship between strikers and service users, and is also likely to boost their standing with the public at large.

Certain coverage reinvents negative stereotyping of mental health service users. The defence of statutorily provided services is seen as a bulwark against the abandonment of vulnerable individuals to the vicissitudes of care in the community supported by a lesser quality of care and a lesser degree of supervision. And also, importantly in the same context, implies or explicitly suggests that the public may be at a greater risk from dangerous individuals. This strand of coverage is not in any way detrimental to the union's profile in the case, and, indeed, could be seen to bolster it. It does, however, undermine solidarity and alliances with empowered service user groups because it either directly exposes the members and activists to damaging stereotypes or reintroduces the notion of paternalism into the relationship with nursing staff. The visibility of such depictions in the coverage chimes in with the aforementioned prevailing psychiatric hegemony of seeing mental 'illness' as of a piece with all other forms of 
illness. Taken together, these examples of media coverage fly in the face of notions of equality and respect within any alliance.

The Manchester dispute was well supported by one local service user group in particular, including many individuals with first hand experiences of the services in question and the direct care provided by Karen and the other strikers. Often the retelling of these experiences would involve positive and warmly expressed recollections of Karen's care in particular. This support was very visible both formally and informally within the various events organised to garner support for the strike. For instance, service user speakers spoke from platforms but also contributed vociferous supportive contributions from the floor.

\section{Analysis of the media coverage}

A number of discursive themes emerge from an analysis of the media coverage of the strike. 75 separate media outputs were located and analysed for a five month period covering the height of the dispute, dating from the $5^{\text {th }}$ November 2007 , following Karen's sacking, to $13^{\text {th }}$ March 2008. These include examples from newspapers (local and national), nursing magazines, and web-sites (including those of broadcast media), and Unison's own output. The local newspapers included: The Manchester Evening News (23), Liverpool Daily Post (1), Burnley Citizen (1), Bolton News (4), Chester Standard (1), Oxford Mail (1), Lancashire Evening Telegraph (1), North East Manchester Advertiser (1). National coverage included: Socialist Worker (9), The Guardian (2), The Independent (1), The Daily Mail (2), BBC News (7),

Channel 4 News (2), Community Care (1), Nursing Times (1), Nursing in Practice (2), Psychminded (1). See Appendix 1 for complete list of articles. Simple thematic analysis was used, and ten distinct themes were identified. The themes themselves are described in more detail below. 
Reinstatement: this theme states the action's aim as reinstatement of Karen following her sacking. A number of other issues where seen to be at stake, and these figure in some of the themes described below.

Whistelblowing: the circumstances that led to the sacking and hence the strike are depicted as an act of speaking out, alerting the public to a perception that management were threatening the stability of services. This was often framed as an issue of freedom of speech. In the majority of coverage it is suggested that Karen's behaviour in breaking the story about the Trust's reorganisation plans was both brave and necessary. This latter point was linked with Karen's role as shop steward, allowing for a positive and wholesome depiction of trade union activism.

Disreputable behaviour: The flip-side to the notion of heroic whistleblowing brings forward the management position that this was an unprofessional act, that undermined due procedure and brought the Trust into disrepute.

Popularity of Karen: A strong theme in the media coverage, which was often revisited over the course of the strike and its aftermath, was Karen's personal qualities and popularity. She is described as popular with colleagues and service users. Other associated coverage points out that she had been seen as a professional of sufficient merit to be promoted to a senior clinical role on the very day that she was first subject to disciplinary action. Her twenty-five years in service was regularly referred to in positive terms and a number of articles quoted the view of independent commentators that her motives were sincere. She was also referred to as an award winning nurse.

Defence of the NHS: This theme brings in the main factors which motivated the actions that precipitated the dispute and links these to issues of long-term 
commitment on the union side, being in the fight for the long-haul and not going to give up. These are largely framed around arguments against cuts and privatisation, linked to anticipation of worsened quality of care for service users and job losses or denuded terms and conditions for staff. This discourse chimes in with wider politics defending the NHS from neo-liberal forces and the encroachment of marketisation, tapping in to public affinity for the NHS as a valued social institution. On occasion, the dispute was explicitly linked to other local privatisation issues, such as campaigning against the involvement of Richard Branson's Virgin group in tendering for primary care services. Some of the complexities of the perceived retreat from State provision, identified with the NHS, were somewhat glossed over in most of the media coverage. The flipside to this is coverage of the management position that the proposed changes are about the improvement of services and quality of care. This was linked to expressed management confidence in winning the dispute.

Disruption to services: As is often the case in industrial disputes, the impact of a strike can often be depicted in confusing ways, with both sides to the dispute having a stake in how this is presented. Management, for instance, might gain from portrayal of the strikers as a negative force, disrupting services. Conversely, they may also need to be able to argue that the strike isn't having any effect and that it is 'business as usual'. Similarly, the strikers may wish to resist their depiction as agents of disruption and argue that any detriment to services is the employers fault, and in any event would be so much worse without the action to defend services. The strikers would certainly not wish to be associated with allegations that the action led to harm to patients. The coverage here ranged across this territory and included references to 'major disruption', 'crippling services', working days lost, and numbers of strikers. Other coverage described strategies to cope with the absence of the strikers, which included transfer of patients out of area and, interestingly, the movement of extra 
staff and beds into the service. The coverage also included instances of patients' complaints because of changes to the service.

Risk in the community: This theme figured in a fair amount of the coverage, and highlighted the possibilities for raising the stakes of risk to the public and for individual service users. Most prominent was the idea of vulnerable individuals being left without appropriate care and support. But there was also the notion of dangerous individuals receiving less supervision such that they might pose a greater risk to the community. This chimes in with widely available representations of mental health and risk, associated with public fear and negative attitudes. These potential risks could be storied either in relation to possible consequences of the strike, or, in support of the union objectives against privatisation. That is the newly constituted, non-NHS, services would be less able to manage risk. Some of the satirical contributions from alternative comedians also evidenced this conflation of mental health and risk, and other examples of negative treatment of mental health in the service of comedy (see Steel 2007).

Criticism of management: this theme gathers together a constellation of negative portrayals of the local NHS management. Some of this is articulated by the union side, but some is also brought forward by patient groups and members of the public. The criticism included the idea that the sacking of Karen was to purposively inhibit staff dissent in the future by rendering them fearful of the consequences of challenging management. These depictions of management motivations were sometimes described in the language of victimisation and vendettas. This was also linked to a feeling that the hard line taken by management was indicative of a desire to damage a strong union branch. Various coverage included statements of no confidence in the management arising from the local Patient and Public Involvement Forum, and other stories that ridiculed management and the Chief Executive in 
particular. One series of stories highlighted this Director's holidaying at a time when, allegedly, she would have been better advised to stay at home and resolve the dispute. This story juxtaposed the richness of the Chief executives holiday arrangements and the hardships facing the strikers and service users. A number of left wing comics added celebrity scorn to the management handling of the strike, and the aforementioned irony of Karen's promotion preceding her dismissal. These critical accounts of management also included suggestions that the management had engaged in the strike in a way that was actually a distraction from their stated aim of improving services.

Public support: this narrative detailed public support and other forms of solidarity with the strike. This included some of the features of public support already mentioned but also included examples of labour movement solidarity, including benefits events for strikers organised by other union branches, demonstrations and rallies and associated rhetoric, support of the North Manchester Service User Forum and the Patient \& Public Involvement Forum. This included personal testimonies and interviews from service users and members of the public. Specific examples of celebrity support and the interest of union leaders and MPs were also noted. Some of the coverage included descriptions of strategies to mobilise support and activist participation, within and beyond the union.

\section{Discursive effects}

There is a complex relationship between public consciousness and media effects, particularly the extent to which media can sway public opinion. It is also important to note that the unions and activists are not in a passive relationship to the media coverage: it is often their accounts of the dispute via public rhetoric, including platform speeches, interview quotes, or formal press releases that define or achieve prominence in any news story. This tendency is typically evident where the local 
news story is raided, sometimes almost verbatim, for deployment by national media. Hence, those in charge of the campaign can influence the content of media representations; and, in some sense, the storying of the campaign in the press $\underline{\text { is }}$ the campaign.

The available discourse that surrounds a strike is not neutral in its effects, and an important focus is the extent to which this enhances or inhibits the potential for radical and creative alliances between workers, service users and other community interest groups. The ten discursive themes identified here can be conceptualised in terms of their potential to promote such alliances and/or promote public support for the strike. The different ways in which the anticipated discursive effects might be located is depicted in the Discourse Matrix (Figure 1.) The discourses have been located on the basis of anticipated likely interaction with public opinion, whilst acknowledging that this is not homogenised.

[Insert Figure 1 about here]

Reflecting on this matrix it becomes apparent that for some forms of discourse there is a trade-off between promoting public support or a solid alliance. This is most obviously associated with the discourse that depicts mental health service users as vulnerable and passive and/or risky and dangerous. Such negative representations of mental health are likely to damage any potential for a radical alliance with service users, but do not harm public support for action which might be presented as likely to protect the community from exposure to these risks. This element of the discourse in the dispute correspond with powerful wider representations of mental health, associated with various stereotypes, public fears and, arguably, government interests. 
The defence of the NHS discourse is difficult to locate, and elements of this discourse could sit in different quadrants of the matrix. The features of this discourse that chime in with mass public affinity for the institution of the NHS would see it situated both promoting public support and potential for alliance with radical elements of the user movement. Arguably, the actual issues at stake in the dispute were more complex than a simple case of privatisation; involving the potential role of voluntary organisations amidst a national policy vogue for 'third sector' provision of services. Confused campaigning and media messages concerning the possibilities for voluntary sector involvement, could damage the potential for wider alliances. For this reason, the placing of this discourse has been split across two locations in the matrix. Cresswell \& Spandler (2008) stress the importance of making connections with progressive third sector organisations many of which cross over with radical user groups. Arguably, the Manchester campaign itself, in the context of a drive to commission services in the third sector, got off to a bad start by criticising HARP a local voluntary sector organisation. Interestingly, some people involved in HARP supported the strike and HARP didn't support the sacking.

Probably reflecting the general positive disposition of the media coverage towards the aims of the strikers, there is no discourse identified that explicitly damages both public opinion and the potential for alliance. This is not necessarily grounds for optimism on the union side, and might reflect the fact that difficult and challenging campaign decisions that could have explored a more progressive politics of mental health were avoided; together with the potential for this to complicate public relations.

\section{Discourse strategy}

The discourse that surrounds strikes is undoubtedly important, and trade unions have been urged to emphasise discourse and discursive practices if they are to retain their value and vitality. The analysis here suggests that one strategy ought to be 
concerned with taking care over the formulation of campaigning messages so as to maximise the potential for key alliances and sustain these for future solidarity and action. Where mental health is central to the dispute, this may mean that difficult challenges lie ahead in concomitantly holding onto wider public support. Attention to the formulation of a progressive politics of mental health, which could be shared with radical user groups and the general public is one way forward. Arguably, this task must go before, or at least run in parallel, with instances of industrial action.

A reflexive relationship between the media coverage and the campaign has been noted. Many of the separate 'stories' in different outlets simply recycle an original story or regurgitate elements of the most current press release. This raises interesting concerns for unions and activists, if they are to invent themselves as 'discourse organisations', where the interaction between public support and the strategic rhetoric is seen as crucial for prosecuting the strike and sustaining solidarity with wider community interest and forms of resistance. A small number of local journalists can be seen as key in setting the tone for coverage of the dispute, even the extension of this to national attention. Given that the local branch of the National Union of Journalists was an active supporter of the strike, and indeed provided office space for the strike committee, there was possibly a missed opportunity to develop a more progressive articulation of the alliance with service users in the dispute.

All of this raises questions around what steps were taken in the course of the dispute to make the most of service user solidarity, including involvement in discussions over strategy and more detailed analysis of the issues at stake. Beyond the resolution of this particular dispute, there are questions surrounding future relationships and the directions these could take. Support for the reinstatement of a valued and respected nurse, carer and colleague in activism is one thing, the shape of future mental health services and the fine detail of any one service in practice is another. A progressive 
solidarity partnership between trade unionists and service users could extend beyond the resolution of the dispute into taking more of a joint stake in future direction and planning of services.

\section{Conclusions}

For Hyman (2007), faced with the burgeoning hegemony of neo-liberalism trade unions must find:

\footnotetext{
Alternative ways of connecting economy and society, work and life, and trade unions should be in the forefront of defining these alternatives. Trade unions need a new vision, even a new utopia if they are to become subjects rather than objects of history. Hyman (2007: 14)
}

In one sense the Manchester nurses' strike has begun this mission. The roots of the dispute, however complexly worked out, are in the neo-liberal encroachment into the UK model of welfare (though the analysis of the voluntary sector in all of this remains messy). The trade union resistance to this was certainly part of a radical politics of contention and concerned with rights and social justice. Importantly, local mental health service user groups actively supported the industrial action, and have been highly visible in doing so. The beginnings of an alliance are there, and there is the potential to build on this for the future.

The analysis of the media coverage presented here is fairly untypical of the general coverage of labour disputes, with the strike reasonably well supported. At least one significant problem, however, stands in the way of future solidarity and alliances with the wider service user movement. Cresswell \& Spandler (2008) argue that the traditional left have yet to take seriously the broader politics of mental health. This is telling in relation to building progressive alliances because it impedes the 
involvement of the more radical sections of the user movement, who were not noticeably involved in supporting the Manchester strike. Hence, the support by local groups for the strike did not move away from the discursive territory as defined by the trade union activists. Those service users who actively supported the strike did so on the basis of 'defending the NHS': focusing on rhetoric about jobs and services rather than challenging ideas about mental health/illness.

The ease with which the union message was taken up in the media might suggest that there were some problems with the discourse of the campaign from the start. Defending the NHS as an icon of social welfare and the appeal to defend the capacity of services to protect the public in a context of risk and mental health are powerful messages that chime in with popular public attitudes. Some of this discourse is radical (challenging neo-liberal forces), some of it is quite reactionary (reifying a negative portrayal of mental health). Other confusions were evident at the very start of the campaign in the conflation of voluntary sector involvement in mental health services with opposition to privatisation. Arguably, the trade union attack on a well respected local voluntary sector agency served to alienate a constituency wellplaced to support the dispute. Perhaps a less confused presentation of the campaign, which thought carefully about mental health politics, might have forced a more critical engagement between the activists and the media. This may have altered the tone of the media coverage, but would arguably have allowed for the development of more broadly based alliances placed on a more stable footing from the outset.

A more effective and egalitarian alliance, that opens up opportunities for envisioning a new politics of mental health and imagines better services for people to be cared for in and staff to work in, must attend both to the media representation of the actors in the dispute and the anticipated effects on the alliance. In one sense this is what is 
meant by trade unions becoming discourse organisations. Further, it could be argued that all public sector strikes will be won or lost depending as much on the discourse of the dispute as the mobilisation of strikers. Allies in this fight must take care over their rhetoric and, crucially, make a point of challenging reactionary depictions and stereotypes. The analysis of the media discourse is not merely a reflection on editorial policy and journalistic licence, lessons to be learnt must encompass the discursive elements of the campaign itself. The discourse matrix presented here illustrates how certain themes evident in both the campaign and the media coverage work to sustain alliances, but others operate to inhibit this potential.

The Manchester strike was arguably well-treated in the media and, if anything, it was the Trust management that received most criticism. The idea of activism as discursive practice is more than public relations or presenting a case to the world, it is also about rethinking understandings of the relevant issues. There is a long tradition of service users and radical workers banding together for progressive causes in health and social care (Spandler 2006). Mental health service users have organised themselves in a dynamic social movement with a positive agenda for change. Many staff and trade unionists share these patient-led objectives, and elements of the trade union movement have begun to show interest in new forms of organisation that reach out to wider communities and forge links across all forms of community activism. This could become a strong alliance that is as much about proactively realising a new politics of mental health, as reacting to the trials and tribulations of neo-liberal assaults on public services, important though this is. Unions and their constituent branches have an interest in forging broadly based community alliances in advance of any dispute or campaign, so that solidarity can be assumed rather than built from scratch on an ad hoc basis (Wills \& Simms 2004). 


\section{References}

Allsop J, Jones K \& Baggott R (2004). Health consumer groups in the UK: a new social movement? Sociology of Health \& Illness 26: 737-756.

Associated Press Worldstream (2002) Nurses strike in protest at 'appalling' conditions in Irish emergency rooms. Associated Press Worldstream. 13 March.

Bayley C (2006). Community bridge building. U (Unison members' magazine) New Year issue.

Brindle D. (1995). End no-strike rule, say 99pc of nurses. The Guardian. 17 May.

Campbell P (1996). The history of the user movement in the United Kingdom. In:

Heller T, Reynolds J, Gomm R, Muston R, Pattison S (eds). Mental Health Matters: A Reader. Macmillan in association with the Open University: Basingstoke.

Carpenter M (1988). Working For Health: The History of COHSE. Lawrence and Wishart: London. 407pp.

Carter B, Poynter G (1999). Unions in a changing climate: MSF and Unison experiences in the new public sector. Industrial Relations Journal 30: 499-513.

Cox P (2008). Looking back and moving forwards - seeking conditions and connections for a radical social work discourse and praxis. Paper presented at Alternative Futures and Popular Protest. $13^{\text {th }}$ International Social Movements Conference. Manchester, March 17-19. 
Cranford C, Ladd D (2003). Community unionism: organising for fair employment in Canada. Just Labour 3: (Fall), 46-59.

Cresswell M, Spandler H (2008). Psychopolitics: Peter Sedgwick's legacy for mental health movements. Paper presented at Alternative Futures and Popular Protest. $13^{\text {th }}$ International Social Movements Conference. Manchester, March 17-19.

Crossley N (1999). Working Utopias and Social Movements: An Investigation Using Case Study Materials from Radical Mental Health Movements in Britain. Sociology 33: 809-830.

Crossley N (2002). Making Sense of Social Movements. Open University Press: Buckingham.

Day M (1995a). Last Ditch Bid to Avert Action. Nursing Times 91: (36) 5.

Day M (1995b). UCLH staff walk out in protest over steward's sacking. Nursing Times 91: (33) 8.

Department of Health and Social Security (1988). The Clinical Nurse Grading Structure. HMSO: London.

Doyal L with Pennell I (1979). The Political Economy Of Health. Pluto Press: London.

Farrow T, O'Brien A (2005). Discourse analysis of newspaper coverage of the 2001/2002 Canterbury, New Zealand mental health nurses' strike. International Journal of Mental Health Nursing 14: 187-195. 
Friend B (1994). A Nurse in the House. Nursing Times 90: (35) 36.

Gavin J (1995). The politics of nursing: a case study - clinical grading. Journal of Advanced Nursing 22: 379-385.

Gray J (1995). Vote is `enduring legacy' of pay campaign. Nursing Standard 9: (41) 5.

Hart C (1994). Behind the Mask. Nurses, Their Unions and Nursing Policy. Bailliere Tindall: London. 297pp

Hart C (2004). Nurses And Politics: The Impact Of Power And Practice. Palgrave: Houndmills. 332pp

Hoerr J (1997). We Can't Eat Prestige: The Women Who Organized Harvard. Temple University Press: Philadelphia. 280pp

Hyman R (2007). How can trade unions act strategically? Industrial Relations in Europe Conference. Centre of Industrial Relations \& Negotiations [CIRN]; 26-28 July 2007; Athens.

Jarley P (2005). Unions as social capital: renewal through a return to the logic of mutual aid? Labor Studies Journal 29: (4) 1-26.

Jennings K, Western G (1997). A right to strike? Nursing Ethics 4: 269-276.

Littman D. (2008). Another politics is possible. Red Pepper. June/July issue. 
McKeown M, Mercer D (2000). Open space: a touch of the blues. ['Super nurses' and the denigration of public service]. Health Service Journal. 10 February, 30.

McKeown M, Spandler H, Cresswell M (2008). View point. Mental Health Today March: 41.

McKeown M, Stowell-Smith M, Foley B (1999). Passivity versus militancy: a Q methodological study of nurses' industrial relations on merseyside. Journal of Advanced Nursing 30: 140-149

Monahan J. (2000). Back from D.C. demonstrations, activists take on nurses strike. Massachusetts Telegram \& Gazette. 25 April.

Phelps-Brown H (1990). The counter-revolution of our time. Industrial Relations 29: (1) 1-14.

Pogatchnik S. (1999). Massive Irish nurses strike divides a troubled nation. Associated Press. 21 October.

Rogers A, Pilgrim D (1991). "Pulling down churches": accounting for the British mental health users movement. Sociology of Health and IIIness 13: 129-148.

Sedgwick P (1982). Psychopolitics. Pluto Press: London. 292pp

Spandler H (2006). Asylum to action: Paddington day hospital, therapeutic communities and beyond. Jessica Kingsley Publications: London. 171pp 
Steel M. (2007). You can't go round telling people you've been sacked. The Independent. 14 November.

Tufts S (1998). Community unionism in Canada and Labor's (re)organization of space. Antipode 30: 227-250.

UNISON (2008) National Branch Seminar. Strategic Influence and Community Campaigning. (Seminar Report, 22 May 2008). Unison: London.

UNISON. (1994). When it comes to goodies, UNISON is at your service. UNISON Magazine 2: (1) 14-15.

Waddington J, Kerr A (1999a). Trying to stem the flow: union membership turnover in the public sector. Industrial Relations Journal 30: 184-196.

Waddington J, Kerr A (1999b). Membership retention in the public sector. Industrial Relations Journal 30: 151-165.

Williamson C (2008). The patient movement as an emancipation movement. Health Expectations 11, 102-112.

Wills J (2001). Community unionism and trade union renewal in the UK: moving beyond the fragments at last? Transactions of the Institute of British Geographers 26: 465-483.

Wills J (2007). Low pay, no way. Red Pepper September.

Wills J, Simms M (2004). Building reciprocal community unionism in the UK. Capital \& Class Spring: (82) 59-84. 
Zoll R (1991). Gewerkschaften as diskurs-organisationen. Gewerkschaftliche Monatshefte 6: 390-399. 


\section{Appendix 1: Media coverage reviewed}

Go Whistle. The Guardian (12/3/2008)

Nurse takes job fight to tribunal. Manchester Evening News (13/02/2008)

Campaigning for Karen Reissmann. Socialist Worker (12/02/2008)

MP is to meet sacked nurse. This Is Lancashire (25/01/2008)

Watchdog backs calls for inquiry. Manchester Evening News (3/01/2008)

Stars gather for Reissmann benefit. Manchester Evening News (17/12/2007)

Karen Reissmann: 'Our fight for NHS is far from over'. Socialist Worker (17/12/2007)

Return to work for health staff. BBC News (17/12/2007)

Manchester nurses back at work after strike. Nursing Times (17/12/2007)

Mental health workers suspend strike. Manchester.com (17/12/2007)

Strike fundraiser. Liverpool Daily Post (17/12/2007)

Mental health nurse row strike suspended. Bolton News (16/12/2007)

Health workers vote to end strike. BBC News (14/12/2007)

We'll support you ever more - pledge to sacked nurse. Bolton News (12/12/2007)

Mental health worker strike to continue. Psychminded.co.uk (12/12/2007)

Nurse loses appeal over dismissal. Nursing in Practice (12/12/2007)

Fight for free speech continues. UNISON (11/12/2007)

Staff to support sacked nurse. This Is Lancashire (11/12/2007)

Protest rally over sacked nurse. BBC News (11/12/2007)

Staff to support sacked nurse. Bolton News (11/12/2007)

Union rally for Reissman. Manchester Evening News (11/12/2007)

Sacked nurse to fight on. Manchester Evening News (11/12/2007)

Karen Reissmann: fury as appeal upholds sacking of NHS activist. Socialist Worker (11/12/2007)

Reissman loses appeal. Manchester Evening News (10/12/2007)

Rallies in support of sacked nurse. Channel 4 News (10/12/2007)

Sacked nurse loses appeal hearing. BBC News (10/12/2007)

Fury as Karen Reissmann sacking upheld. Socialist Worker (10/12/2007) 
Severe psychiatric care 'shame'. Manchester Evening News (6/12/2007)

Protest backs sacked mental-health worker. Bolton News (6/12/2007)

Protest backs sacked mental-health worker. This Is Lancashire (6/12/2007)

NHS staff protest over sacked nurse. Nursing in Practice (6/12/2007)

Unions gear up for co-ordinated campaign. UNISON (5/12/2007)

Nurses hold 'silent' protest. Manchester Evening News (5/12/2007)

NHS staff strike in support of 'whistleblower'. Society Guardian Unlimited (5/12/2007)

Health staff protest at 'unjust' sacking of nurse. Healthcare Republic (5/12/2007)

Thousands of health workers protest after nurse was sacked for speaking out against service cuts. Daily Mail (5/12/2007)

Health workers to support sacked nurse. Chester Standard (5/12/2007)

UNISON National "Solidarity Day" for Sacked Nurse. UNISON (4/12/2007)

Doctors support sacked nurse. Manchester Evening News (4/12/2007)

Strikes feared over sacked nurse. Channel 4 News (4/12/2007)

Crucial week in fight for Karen Reissmann. Socialist Worker (4/12/2007)

Union seeks justice for Karen. UNISON (3/12/2007)

Trio to decide fate of sacked nurse. Manchester Evening News (3/12/2007)

Sacked nurse's appeal case starts. BBC News (3/12/2007)

Unjust sacking. Oxford Mail (2/12/2007)

Day of protest for Karen. Manchester Evening News (30/11/2007)

Nurses' fury over wage cuts. Manchester Evening News (29/11/2007)

Shameless writer backs sacked nurse. Lancashire Evening Telegraph (26/11/2007)

Trade unionist sacked for press interview to appeal. Press Gazette (26/11/2007)

Shameless writer backs sacked nurse Burnley Citizen (26/11/2007)

Reissman: What was said at the rally. Manchester Evening News (25/11/2007)

Sacked nurse gets star support. Manchester Evening News (25/11/2007)

Protesters support sacked nurse. BBC News (24/11/2007)

Talks to end health staff strike. BBC News (22/11/2007)

Nurses row escalates. Manchester Evening News (22/11/2007) 
Growing solidarity for Karen Reissmann. Socialist Worker (20/11/2007)

Strike row boss ambushed. Manchester Evening News (20/11/2007)

Cover call could spark strikes across the region. Manchester Evening News (17/11/2007)

Sacked nurse takes case to Europe. BBC News (15/11/2007)

Whistleblower calls for action. North East Manchester Advertiser (5/11/2007)

Councillors split over strike Manchester Evening News (14/11/2007)

Mark Steel: You can't go round telling people you've been sacked. The Independent (14/11/2007)

Money pours in to Karen Reissmann strike fund. Socialist Worker (13/11/2007)

All-out strike over sacked health rep. Socialist Worker (13/11/2007)

Crisis care as strikes take hold. Manchester Evening News (12/11/2007)

Strike-row boss in desert storm. Manchester Evening News (9/11/2007)

Manchester health workers strike in support of sacked activist. UNISON (8/11/2007)

Nurses speak out for Karen. Manchester Evening News (8/11/2007)

Nurses strike for Reissmann. Manchester Evening News (8/11/2007)

Mental health workers to strike again. Manchester.com (6/11/2007)

Nurse sacked for speaking to the media about NHS Trusts. Daily Mail (6/11/2007)

Manchester staff to strike over nurse sacking. Community Care $(6 / 11 / 2007)$

Leading Unison activist Karen Reissmann sacked. Socialist Worker (5/11/2007)

Nurses union leader sacked. Manchester Evening News (5/11/2007) 


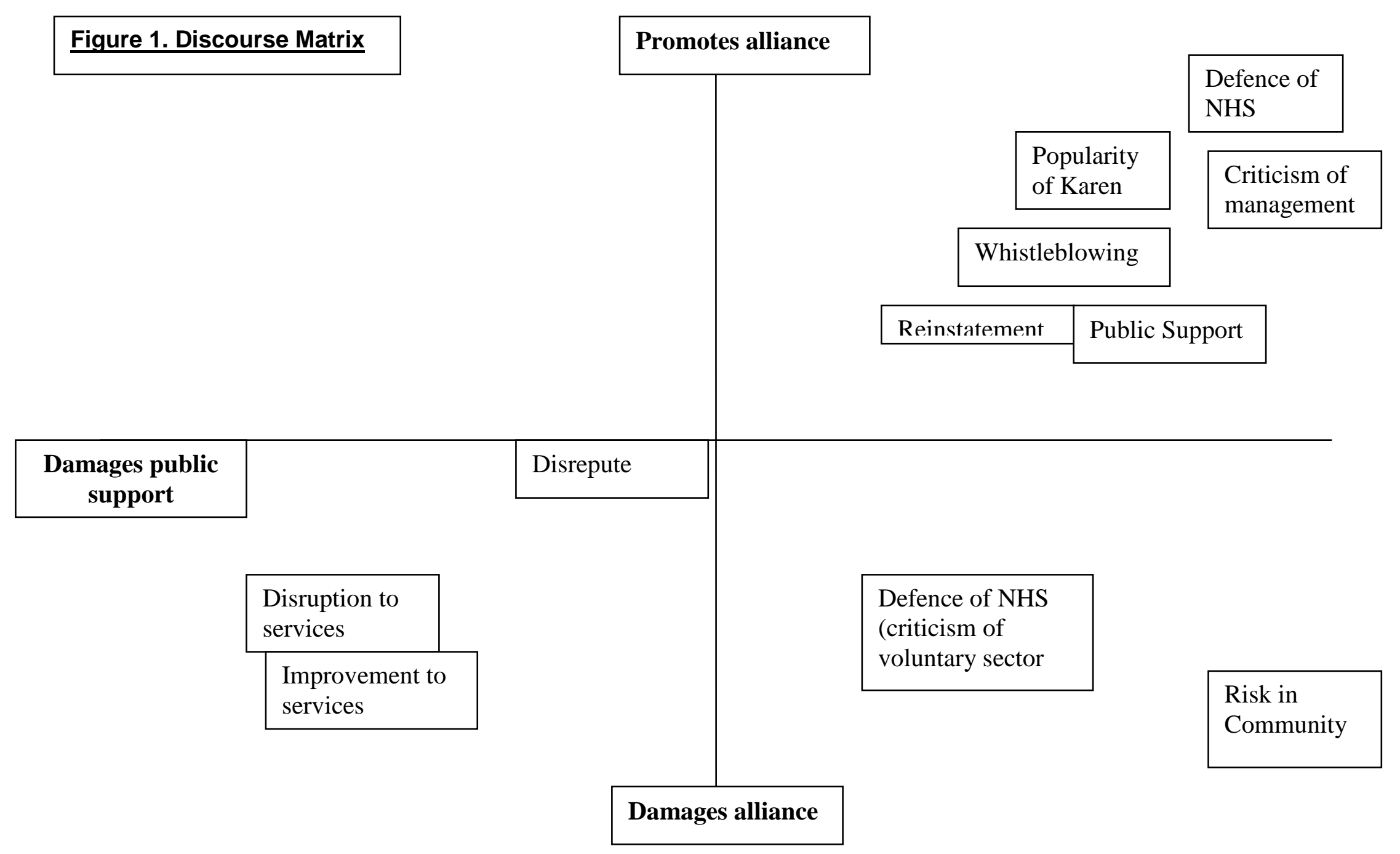

